JPH: Jurnal Pembaharuan Hukum

Volume 8, Number 2, August 2021

\title{
STATE'S READINESS MOBILITY IN APPLYING NUCLEAR TECHNOLOGY AS ENERY DEVELOPMENT IN LEGAL PERSPECTIVE
}

\author{
Saleh Raed Shatat \\ University of Jordania \\ salehshatat@gmail.com \\ Ade Riusma Ariyana \\ University of Selamat Sri \\ aderiusma@gmail.com \\ Devina Arifani \\ AEJI Malaysia \\ devinaarifani12@gmail.com
}

\begin{abstract}
The states Nuclear Program is a program to build and utilize nuclear science and technology both in the non-energy sector and in the energy sector for peaceful purposes. Utilization of non-energy in Indonesia has developed quite advanced. The use of nuclear power in every countries covers various fields such as health, research and industry. Indonesia's readiness in implementing nuclear energy is carried out by ratifying international conventions, issuing laws, and issuing regulations from the Nuclear Energy Supervisory Agency, readiness in the field of infrastructure used to strengthen technology, and in Indonesia is committed to reducing $26 \%$ of greenhouse gas emissions in the year 2020. A nuclear power plant or nuclear power plant is a thermal power plant that uses one or more nuclear reactors as a heat source. The working principle of a nuclear power plant is almost the same as a steam power plant, using high pressure steam to turn a turbine. The rotation of the turbine is converted into electrical energy. The difference is the heat source used to generate heat. $A$ nuclear power plant uses uranium as its heat source. The fission reaction (fission) of the uranium nucleus produces enormous heat energy. The power of a nuclear power plant ranges from 40 MWe to 2000 MWe, and a nuclear power plant built in 2005 has a power distribution from $600 \mathrm{MWe}$ to $1200 \mathrm{MWe}$. As of 2015 there are 437 nuclear power plants operating in the world, which in total generate about $1 / 6$ of the world's electrical energy. To date, around 66 nuclear power plants are being built in various countries, including China with 28 units, Russia with 11 units, India with 7 units, the United Arab Emirates with 4 units, South Korea with 4 units, Pakistan and Taiwan with 2 units each. Nuclear power plants are categorized based on the type of reactor used. However, in some plants that have several separate reactor units, it is possible to use reactor types that are fueled such as Uranium and Plutonium.
\end{abstract}

Keywords; Energy; Development; Legality; Nuclear; Sustainable; 


\section{A. INTRODUCTION}

National economic growth to achieve a prosperous and prosperous society rests heavily on driving factors for national energy growth. On the other hand, population growth, an increase in the need for living standards, limited energy resources and an increase in population are challenges for meeting energy needs, especially electricity in every states/countries. One solution, the growth of electricity energy in Indonesia today must be based on the diversity of energy resources, including new and renewable resources.

Responding to this challenge, new and renewable energy programs in Indonesia must be prepared not only in policy corridors. As mandated in the Law, this is evidenced in the aspects of control and application. For this reason, a systematic and sustainable strategy is needed on strengthening technology in order to achieve energy security.

The most widely accepted definition of sustainable development by countries, as contained in the 1987 UN report on Our Common Future ${ }^{1}$ is: "Sustainable development is development that can meet the needs of the present without worrying about the ability of future generations to meet their own needs". This report is commonly referred to as the Brundtland Report $1^{2}$, who notes that the definition of sustainable development depends on two main ideas, viz $^{3}$ : the concept of "needs", in particular the basic needs of the poor, whose main priority should be given; and ideas of the limitations imposed by technological states and social organizations on the ability of the environment to meet present and future needs.

The main concern of the concept of sustainable development today can be seen as a result of the definition provided by the Brundtland report. In general, this can be described as a concern about ${ }^{4}$ : limited resource depletion; the carrying capacity of the ecosystem; intergenerational equity; intragenerational equity; material requirements for human development; and non-material needs for human development.

Issues that arise in the context of this concern are grouped into three main sections, according to the three "pillars" outlined in the Johannesburg Declaration on Sustainable Development in the 2002 United Nations General Declaration on Sustainable Development. ${ }^{5}$ First, the pillars of a sustainable economy relate to the maintenance, accumulation and use of various categories of capital: human made (infrastructure and machinery), nature (mineral resources, forests, clean air and water), and social / human capital (institutions and knowledge); Second, the environmental pillar includes the preservation of natural resources and biodiversity, as well as the protection

1 United Nations, Development and International Co-operation: Environment, Report of The World Commission on Environment and Development, UN document, UN, New York, 1987.

2 Gro Harlem Brundtland, The Report Our Common Future, by the World Commission on Environment and Development, 1987.

3 International Atomic Energy Agency, Nuclear Power and Sustainable Development, Marketing and Sales Unit, Publishing Section of International Atomic Energy Agency, Vienna, 2016, page.3.

4 Ibid.

5 United Nations, Plan of Implementation of the World Summit on 2002. 
of habitats and ecosystems. The main concern of this pillar is to ensure that natural capital, including the carrying capacity of ecosystems (as determined by the nature of critical biogeochemical cycles) is not depleted;

Third, the social pillar includes "needs", as defined in the Brundtland report. Needs that are not limited to basic necessities, such as food, water, energy, shelter and health, but are extended to fields that include education, recreation, culture, political activity, good governance, competent institutions, social relations, and justice both intra and intergenerational.

Sustainable development is characterized by strong notions of sustainability and weak sustainability. The main difference between these two concepts lies in the willingness to accept the possibility of substitutions between different forms of capital: natural (mineral resources and ecosystem carrying capacity), man-made (infrastructure and machinery), and social / human (institutions and knowledge). Strong proponents of sustainability argue that some types of natural capital cannot be replaced by human resources or social capital. Depletion of this type of natural capital is an irreversible loss and should be avoided. Conversely, weak advocates of sustainability believe that human and social capital can replace natural capital forever ${ }^{6}$.

The issue of sustainable development that arises in the context of these three pillars creates linkages, which means that the relationship between one pillar and another is closely related, and what happens to one pillar will have an impact on the other pillars. Basic human needs such as peace, development and the environment have been the focus of the Brundtland report. This has been recognized by political leaders, scientists, high-level panels, the global UN conference and the Summit (hereinafter referred to as the "Summit"). So that in September 2015, the United Nations has adopted a post-2015 development agenda, in which the agenda sets out an action plan until 2030 for humanity, planet and prosperity.

The main agenda that has been set is a set of new global Sustainable Development Goals (hereinafter referred to as "SDGs") to build the creation of the Millennium Development Goals (hereinafter referred to as "MDGs"). This agenda aims to shift the world to a sustainable path where environmental sustainability, social inclusion and economic development are on an equal footing. In particular, the SDGs have set goals for the social sector and combine goals on environmental quality (related to climate change, loss of biodiversity, deforestation and oceans) and sustainable economic progress (sustainable energy sources, building sustainable cities, and promoting sustainable economic growth). Although the 17 SDGs are separate elements, however, there are strong linkages that connect the SDGs. The integrated nature of the SDGs balances the three dimensions of sustainable development: economic, social and environmental ${ }^{7}$.

6 International Atomic Energy Agency, Nuclear Power and Sustainable Development, Op. Cit., page. 4 See, Neumayer, E., Weak Versus Strong Sustainability, Edward Elgar Publishing, Cheltenham, 2003.

7 International Atomic Energy Agency, Nuclear Power and Sustainable Development, Ibid., page. 6 


\section{B. RESEARCH METHODS}

This research is a qualitative research. Qualitative research is the collection of data in a natural setting with the intention of interpreting the phenomena that occur where the researcher is the key instrument, and the results of qualitative research emphasize the meaning more than generalization. ${ }^{8}$ The data collection technique used in this research is documentation study.

\section{RESULTS AND DISCUSSION}

\section{Energy}

The Indonesian Nuclear Program is an Indonesian program to develop and utilize nuclear science and technology both in the nonenergy sector and in the energy sector for peaceful purposes. Utilization of non-energy in Indonesia has developed quite advanced. Meanwhile in the energy sector (electricity generation), until 2011 Indonesia was still trying to get public support, even though it was considered by the international community that Indonesia was quite capable and it was time to use it. ${ }^{9}$.

The development and application of nuclear technology in Indonesia began with the establishment of the State Committee for Radioactivity Investigation in 1954. The State Committee has the task of investigating the possibility of radioactive fallout from nuclear weapons testing in the Pacific Ocean.

In its development to further increase mastery in the field of nuclear science and technology, in 1965 the operation of the first atomic reactor (Triga Mark II) was inaugurated in Bandung. Then successively, several $R$ \& $D$ facilities were also built in various research centers, including the Pasar Jumat, Jakarta Atomic Energy Research Center (1966), the GAMA Atomic Energy Research Center, Yogyakarta (1967), and a 30 MW Multi Purpose Reactor (1987). ) accompanied by supporting facilities, such as: fuel fabrication and research, reactor safety testing, radioactive waste management and other nuclear facilities ${ }^{10}$.

Broadly speaking, nuclear in Indonesia is developed into 2 (two) major classifications, namely for energy and non-energy. Since the $1970 \mathrm{~s}$ the Indonesian government has initiated the idea that nuclear should be developed in the use of electrical energy. This great desire was shown by holding seminars involving universities in Indonesia, the Research and Development Institute, and the Ministry of Energy. This is done so that new ideas are formed from related institutions to implement nuclear energy in the field of electricity generation due to the increasingly limited energy reserves in Indonesia. Nuclear is seen as an energy source with

8 Anggito, A., \& Setiawan, J., Qualitative Research Methodology, CV Trace (Publisher Footprint), 2018

9 Eko Madi Parmanto, Head of Legal, Public Relations and Cooperation Bureau of the National Atomic Energy Agency-BATAN, Interview, BATAN Head 11 September 2017.

10 Ibid. 
enormous potential which is shown by the development of nuclear energy in the field of technology, safety and has implemented nuclear energy in the form of nuclear power plant development in developed and developing countries, Indonesia is one of the countries that will consider the construction of nuclear power plants with all the advantages of nuclear energy. The readiness of the Indonesian government to build nuclear power plants is shown by preparing mastery of technology and seeking human resources who have the capacity to develop nuclear energy. Technology and human resources are related and synergized, which have been socialized to the community The readiness of the Indonesian government to build nuclear power plants is demonstrated by preparing to master technology and seeking human resources with the capacity to develop nuclear energy. Technology and human resources are related and synergized, which have been disseminated to society The readiness of the Indonesian government to build nuclear power plants is shown by preparing mastery of technology and seeking human resources who have the capacity to develop nuclear energy. Technology and human resources are related and synergized, which have been disseminated to society ${ }^{11}$.

In 1987, with high enthusiasm, Indonesia built a very sophisticated nuclear facility, the facility was related to efforts to master technology. This reactor is the main facility in mastering technology or as a research reactor that includes technology for operation, construction, maintenance and fostering of human resources in operation, with the nuclear reactor facilities being sufficient facilities for technological control. For research, research reactors have been made in Indonesia, namely ${ }^{12}$ :

a. Bandung West Java. Bandung Nuclear Energy Research Center (PPTN). (the Triga Mark II reactor - with a capacity of $250 \mathrm{~kW}$ was inaugurated in 1965, then the capacity was increased to $2 \mathrm{MW}$ in 2000).

b. Yogyakarta, Special Region (Kartini nuclear research reactor - 100 kW operating capacity since 1979).

c. Serpong (Banten). (MPR RSG-GA Siwabessy nuclear research reactor - with a capacity of 30 MW was inaugurated in 1987).

Various locations that have been studied are eligible as potential sites to build reactors to produce nuclear power plants in Muria, Central Java and Bangka, Bangka Belitung Province.

In addition to the construction of reactors, there are also facilities for radioactive waste management, which is a source of public concern, as well as facilities for making nuclear fuel, a safety development facility in the form of simulators used for BATAN researchers if a reactor occurs anomaly or deviations from normal conditions, testing the capacity to be

11 Eko Madi Parmanto, Head of Legal, Public Relations and Cooperation Bureau of the National Atomic Energy Agency-BATAN, Interview, BATAN Head 11 September 2017.

12 Ibid. 
increased and decreased, and testing if the power goes out and from the tests that are carried out require serious efforts. So that if Indonesia has a nuclear power plant, Indonesia can operate the nuclear power plant safely and safely in the field of technology. In the field of natural resources, BATAN collaborates with related institutions that have experience in exploring various places in Indonesia, for example in Kalimantan, in Sulawesi, in Papua and map how much uranium fuel Indonesia has. The results of the mapping will be processed to determine the supply needs of Indonesia in the long term ${ }^{13}$.

\section{Non-energy}

d. Agriculture

In the non-energy sector, nuclear has been used in various fields, for example in agriculture, industry, health, environment, and water use. In the food sector, nuclear is used to improve the quality of production in order to meet the food needs of all Indonesian people, and to avoid a food crisis.

Nuclear technology can be one of the technologies used in the field of food security by increasing productivity, preventing disease or food pests, against climate change, against plant mutations, and food preservation, so that with this radiation technique the seeds of food plants can be strengthened, increasing production, drought resistant, and can be used for post-harvest food that is vulnerable. Radiation systems, can be used to kill microbes, fungi, and putrefaction in foodstuffs, as well as for food preservation processes such as in animal and vegetable products ${ }^{14}$.

e. Industry

In the industrial field, nuclear technology is used for the oil and gas exploration process, to determine the nature of lithography ${ }^{15}$ nor porosity ${ }^{16}$ Nuclear energy radiation systems can also help design road construction, measure moisture and density of soil, asphalt, and concrete.

The nuclear energy radiation system is used for industrial radiography, determination of process homogeneity, environmental management in the feasibility study of tools and materials for companies engaged in engineering midwives, modification of materials to produce high-quality plastics by irradiation processes, radiocarbon dating which is used to determine the age of buildings and ancient objects. In archeology midwives, a logging technique to measure the depth of boreholes with a depth below the ground to

13 Eko Madi Parmanto, Head of Legal, Public Relations and Cooperation Bureau of the National Atomic Energy Agency-BATAN, Interview, BATAN Head 11 September 2017.

14 Ibid.

15 Lithography is a method for printing on smooth surfaces, as well as a method for producing semiconductors and equipment for Micro Electro Mechanical Systems.

16 Porosity is a measure of the free space between materials, and is the fraction of the volume of free space to the total volume, which is a value between 0 and 1 , or as a percentage between $0-100 \%$. 
observe the presence of gas and petroleum in a layer of soil, control the thickness of materials, preservation of wood materials and art items, and to detect defects in material ${ }^{17}$.

\section{Environment}

In the environmental sector, there are several industrial estates which are often found to dispose of their waste in an inappropriate place. By using the neutron analysis activation technique, it can analyze the sample. The sample is fired with neutrons and light spectra so that it can show which elements are and how much they contain. So if this can be done to take samples of air, sea water and river water, it can be seen if these things are polluted or not. So that it can easily help the Indonesian government in terms of monitoring environmental conditions for pollutants and becoming a policy consideration ${ }^{18}$.

\section{Health}

In the health sector, nuclear technology is used for nuclear medicine which uses open sources of radiation derived from the disintegration of artificial radionuclide nuclei, to study physiological, anatomical and biochemical changes, so that it can be used for diagnostic, therapeutic and medical research purposes. In nuclear medicine, radioisotopes can be inserted into the patient's body (invivo studies) or only reacted with biological substances such as blood, stomach fluids, urine and so on, which are taken from the patient's body which is known as an in-vitro study (in a glass experiment). Nuclear medical examination helps a lot in supporting the diagnosis of various diseases such as coronary heart disease, adenoids, kidney function disorders, determine the stage of cancer by detecting its spread in the bone, detecting bleeding in the digestive tract and determining its location, and much more that can be obtained from diagnosis with the application of nuclear technology which is currently growing rapidly. Besides helping to make a diagnosis, nuclear medicine also plays a role in the therapy of certain diseases, such as adenoids cancer, adenoids hyper function that is persistent with the administration of non-radiation drugs, red blood cell malignancy, inflammation (inflammation) of the joints that is difficult to control using therapy. ordinary medicine. If for diagnostic purposes, radioisotopes are given in very small doses, ${ }^{19}$.

In Indonesia, nuclear medicine was introduced in the late 1960s, after the first Indonesian atomic reactor began operating in Bandung. Several Indonesian experts assisted by experts from abroad have initiated the establishment of a nuclear medicine unit at the Nuclear Engineering Research and Development Center in Bandung. This unit is

17 Eko Madi Parmanto, Head of Legal, Public Relations and Cooperation Bureau of the National Atomic Energy Agency-BATAN, Interview, BATAN Head 11 September 2017.

18 Ibid.

19 Eko Madi Parmanto, Head of Legal, Public Relations and Cooperation Bureau of the National Atomic Energy Agency-BATAN, Interview, BATAN Head 11 September 2017. 
the embryo of the Hasan Sadikin Hospital Nuclear Medicine Unit, Faculty of Medicine, Padjadjaran University. Followed by the next units in Jakarta (RSCM, RSPP, RS Gatot Subroto) and in Surabaya (RS Sutomo). In the 1980s, the next nuclear medicine units were established at Sardjito Hospital (Yogyakarta), Kariadi Hospital (Semarang), Harapan Kita Heart Hospital (Jakarta) and Fatmawati Hospital (Jakarta). ${ }^{20}$.

Nuclear technology is not only used in the field of nuclear medicine, but is also used for neutron activation techniques, determination of bone fragility, with a bone densitometer, three dimentional conformal radiotherapy (3d-Crt), and sterilization of medical devices.

\section{Human Resources}

Preparation of Human Resources (hereinafter referred to as "HR) is an initial work in the framework of the construction of nuclear power plants, Indonesia is a country that is currently carrying out the development of nuclear power plants, so the preparation of human resources must be handled seriously ${ }^{21}$. On the basis of practical implications, efforts have been developed to prepare human resources through universities, educational and training institutions, including the BATAN Education and Training Center which has nuclear facilities in Indonesia (nuclear reactors and laboratories). Collaboration between the BATAN Education and Training Center with other institutions related to PLTN, such as BAPETEN, PLN, the Ministry of Energy and Mineral Resources can establish a Nuclear Energy Introduction Education and Training as an effort to prepare nuclear qualified human resources ${ }^{22}$. Systematic Approach To Training (hereinafter referred to as "SAT) is an education and training system to produce qualified human resources in the nuclear field required by a nuclear power plant project. This SAT has been used by countries that have nuclear power plants, because it has been proven to be able to attain and maintain HR competence in the nuclear field. The IAEA itself has recommended the SAT as an education and training system for use by countries that will initiate nuclear power projects $^{23}$.

Listed in Law no. 17 of 2007 concerning the 2005-2025 long-term development plan that Indonesia has started to utilize nuclear power for power plants by considering the safety factor strictly in the III RPJM, which is between 2015-2019. Because the HR development program is

20 Eko Madi Parmanto, Head of Legal, Public Relations and Cooperation Bureau of the National Atomic Energy Agency-BATAN, Interview, BATAN Head 11 September 2017.

21 Song Suk Chae, End Of Mission Report, Support For The First Nuclear Power Plant, IAEA, Viena, 1995.

22 Tecdoc 525, Guide Book On Training To Establish And Maintain The Qualification And Competence Of Nuclear Power Plant Oprations Personnel, IAEA, Vienna, 1998, page. 1121, 146-151.

23 Wisnu Arya Wardhana, Preparation of Human Resources for the Preparation, Construction and Operation of NPPS in Indonesia, Research results for the Scientific Oration of the Main Widyaiswara, Pusdiklat BATAN Jakarta, 2006, page. 128 
an activity that requires a long-term commitment, the PLTN HR preparation activities must be carried out immediately, although until now there has been no official decision from the government to initiate nuclear power plant construction. Thus, the Ministry of Energy and Mineral Resources in 2008 formed a national team for "PLTN HR development", in which the Ministry of Energy and Mineral Resources collaborates with the Ministry of Manpower, the Ministry of Research and Technology, BATAN, BAPETEN, and PLN. One of the tasks that has been carried out is the preparation of technical documents that discuss ${ }^{24}$ :

a. Requirements for NPP personnel, including quantitative and qualitative requirements for each position in the NPP facility, as well as educational, experience, and training requirements.

b. The existing human resource development infrastructure in Indonesia includes the education system, training and personnel certification.

c. Action plan for the preparation of NPP personnel which includes the preparation of Personnel Competency Standards and a training scheme for NPP personnel.

In addition, the Center for Education and Training - BATAN has also started to carry out several activities related to PLTN development plans, namely preparing NPP training facilities and conducting basic nuclear power training ("Reactor Engineering and Safety I") which is an adoption of similar training held by Nuclear Human Resource Development Center (NuHRDeC) - Japan Atomic Energy Agency $(\mathrm{JAEA})^{25}$.

Head of BATAN, Djarot Sulistyo Wisnu Broto said that Indonesian human resources are capable of building and managing nuclear power plants. Based on a survey conducted by BATAN in 2015, Indonesian people's acceptance of nuclear power plants is increasing. The survey, which involved 4,000 respondents, showed the level of public acceptance of nuclear power plants increased to 75 percent from 70 percent in $2014^{26}$.

The definite step taken by BATAN to develop Indonesian human resources in nuclear technology is to establish an infrastructure for human resource development, namely by providing nuclear education at domestic universities such as ${ }^{27}$ :

a. Gajah Mada University - Yogyakarta: offers a Nuclear Engineering study program in the Engineering Physics Department - Faculty of Engineering for the undergraduate level.

24 Hendriyanto Haditjahyono, Preparation of HR for the First Nuclear Power, STTN_BATAN and the Faculty of Science UIN SUKA in the VI National Seminar on Nuclear Technology HR, Yogyakarta, 2010

25 Ibid., page. 844

26 Djarot Sulistyo Wisnu Broto, Indonesian HR Able to Build PLTN, Library of Nuclear Energy Supervisory Agency - BAPETEN, 2016,

27 Hendriyanto Haditjahyono, Preparation of Human Resources for the First Nuclear Power Plant, 2010, Op. Cit., page. 845 
b. Bandung Institute of Technology - Bandung: offers specialization in Reactor Physics in the Department of Physics - Faculty of Mathematics and Natural Sciences and specialization of nuclear power plants in the study program "new and renewable energy" Faculty of Engineering for undergraduate, postgraduate and doctoral levels.

c. University of Indonesia - Jakarta: offers a Medical Physics study program in the Engineering Physics Department - Faculty of Engineering for undergraduate and postgraduate levels.

d. Padjadjaran University - Bandung: offers specialization in "nuclear medicine" at the Faculty of Medicine for Masters level (specialist I).

Besides several state universities, BATAN also has an official school, namely the College of Nuclear Technology (STTN) in Yogyakarta. STTN is a diploma level 4 (D4) education which has 3 (three) study programs, namely electromechanics, instrumentation, and technochemistry. Center for Education and Training - BATAN was formed in 1980 and has the task of carrying out education and training in the field of nuclear science and technology. Center for Education and Training conducts nuclear training for BATAN staff as well as for nuclear technology users ${ }^{28}$.

The types of technical training held by the Center for Education and Training - BATAN (self-management training) are grouped into:

a. Isotopes and Radiation

b. Nuclear Fuels and Nuclear Materials

c. Nuclear Installation and Instrumentation

d. Reactors and Nuclear Energy

e. Nuclear and Radiation Safety

In addition to conducting self-managed training (in-house training), Center for Education and Training - BATAN also manages or sends staff for training abroad in the framework of cooperation with other countries or other international / regional institutions, for example sending some technical staff to Korea and Japan to study nuclear power plant technology.

In order to fulfill safety requirements as well as international provisions, several positions or positions related to nuclear or radiation safety can only be performed by personnel who have a Work Permit (hereinafter referred to as "SIB"). So that BATAN collaborates with BAPETEN to hold personnel certification indicated by a system or mechanism for obtaining a license in the nuclear sector with a position or position that must have a license or SIB, based on the Regulation of the Head of BAPETEN No. 10 of 2008 are as follows ${ }^{29}$ :

a. Radiation Protection Officer for nuclear installations

b. Reactor Operators and Supervisors

28 Ibid.

29 Head of BAPETEN Regulation No. 10 of 2008 
c. Reactor Maintenance Officer and Technician

d. Registrar and Supervisor of Nuclear Materials

It is true that the aforementioned provisions are intended for research nuclear reactors, but since PLTN is also a nuclear facility (nuclear reactor) it seems that this provision will also apply to nuclear power plant facilities. In addition, the Ministry of Energy and Mineral Resources also enforces personnel certification for conventional power plant operators so that NPP operators need to meet these two requirements.

It is assumed that the first nuclear power plant construction project in Indonesia will take a "turn-key project" scheme so that the PLTN HR preparation program focuses more on the human resources who will be involved in the commercial operation of nuclear power plants. Meanwhile, at the physical construction stage, Indonesian human resources are certainly better prepared because they are experienced in building various types of conventional power plants. Basically, the competence of personnel to operate nuclear power plants can be divided into two, namely for those working in the nuclear area (nuclear island) and in the non-nuclear area (non-nuclear island). ${ }^{30}$.

Currently, Indonesia does not have a PLTN, even though Indonesia already operates many power plants, for example PLTU, PLTD, PLTG and so on. Therefore, there are actually a lot of competent human resources to work in nuclear power plants, especially in non-nuclear areas, with a little addition of basic nuclear competencies.

The schematic below shows that all personnel who work in a nuclear power plant, both on a nuclear island and a non-nuclear island, must have basic nuclear competence, namely by following the Basic Nuclear Energy Training. After that, they will be divided into two groups depending on their work area, those who work in the nuclear island area must have special nuclear competence, while those who work in nonnuclear island areas must have special competence in electricity. ${ }^{31}$.

If the government's decision to start PLTN construction has been issued, there will be a lot of requests for training on PLTN, therefore BATAN needs to anticipate these needs by preparing special training facilities for PLTN. The preparation of this training facility includes four aspects, namely aspects of the organization, instructors, training programs, and aspects of training facilities and infrastructure. The task of the NPP training facility is to carry out basic training for personnel who will work at the NPP facility as well as qualification and refresher training for workers at the NPP facility, while its functions are:

a. analyze training needs, design and develop training, conduct training and evaluate training.

30 Hendriyanto Haditjahyono, 2010, Preparation of Human Resources for the First Nuclear Power Plant, Op. Cit., page. 846

31 Hendriyanto Haditjahyono, 2010, Preparation of Human Resources for the First Nuclear Power Plant, Loc. Cit., page. 845 
b. carry out learning and guidance activities, as well as knowledge management.

c. carry out personnel administration, finance, and equipment.

Currently, by utilizing the available resources, some of the functions of the PLTN training facility mentioned above have been carried out by the Center for Education and Training - BATAN with the support of other BATAN work unit laboratory facilities such as the Multipurpose Reactor Center (PRSB) and the Center for Accelerator and Material Process Technology PTAPB). Some of the activities that are being carried out in 2010 by the Center for Education and Training - BATAN are supported by experts from several other work units, namely:

a. Preparation of Competency Training Standards (SLK) documents, which are technical (academic) guidelines for conducting training, which include curriculum, syllabus and teaching plans. This document refers to the Personnel Competency Standards (SKP) that have been compiled by the National Team for HRD PLTN.

b. Preparation of training instructors, namely by sending 3 (three) BATAN staff to participate in the TOT at the Nuclear Human Resource Development Center (NuHRDeC) - Japan Atomic Energy Agency (JAEA) for 2 (two) months with the topic "Reactor Engineering" and "Reactor Safety ".

c. The implementation of the "Reactor Engineering and Safety Level I" training which will become the "embryo" of the basic nuclear power training for all NPP personnel (level 0 on the standard map of nuclear power plant personnel competency). This training is an adoption of a similar training held by NuHRDeC - JAEA and received technical assistance in the form of teaching staff from Japan.

d. Launching the undergraduate scholarship program for the field of study supporting nuclear science and technology. With this scholarship program, the interest of the younger generation in the field of study supporting nuclear science and technology is expected to increase so that there will be a sufficient number of nuclear scholars in the future.

\section{Implementation of the Paris Agreement (National Determined Contribution-NDC) For Combatting the Climate Change Impacts}

Indonesia is a growing country with a stable democracy and the fourth largest population in the world. Although economic growth has continued to increase over the past decade, around $11 \%$ of Indonesia's population is still below the poverty line. To alleviate poverty, the Government of Indonesia is projecting economic development to reach at least $5 \%$ per year in order to reduce the poverty rate to below $4 \%$ in 2025 as mandated in the law, including "that everyone has the right to live a decent and healthy life". Considering that the impacts of climate change are beginning to be felt, Indonesia is still seeking a balance 
between present and future development and priorities for reducing poverty ${ }^{32}$.

In 2010, the Government of Indonesia launched a GHG emission reduction target of $26 \%$ by 2020 , and up to $41 \%$ if there is international support, compared to the business as usual scenario in 2020. The current Indonesian government, under the leadership of President Joko Widodo, has determined 9 (nine) national development priority actions as outlined in the Nawa Cita. Nawa Cita covers, among others, protecting the entire nation and providing a sense of security to all citizens, developing Indonesia from the periphery by strengthening regions and villages within the framework of a unitary state, improving the quality of Indonesian human life, increasing people's productivity and competitiveness in the international market.

Given Indonesia's important geographic position in the global ocean conveyor belt (thermohaline circulation), the largest archipelago country and its tropical rainforests which are rich in biodiversity, high reserves of carbon value and energy and mineral resources, Indonesia is known for its role in fighting climate change. However, Indonesia is also vulnerable to natural disasters which will be exacerbated by climate change, especially in low-lying areas throughout the archipelago. Therefore, Indonesia views comprehensive land and sea-based adaptation and mitigation efforts as a strategic consideration in achieving climate security related to food, water and energy.

Nationally Determined Contribution (NDC) Indonesia outlines Indonesia's transition to a low emission and climate resilient future. The NDC illustrates increased action and supportive conditions during the 2015-2019 period which will serve as a basis for setting more ambitious goals after 2020, which will contribute to efforts to prevent a $20 \mathrm{C}$ rise in global temperatures and pursue efforts to limit global temperature increases by $1.50 \mathrm{C}$ compared to $1.50 \mathrm{C}$. pre-industrial times. For the period 2020 and beyond, Indonesia views the achievement of archipelagic climate resilience as a result of implementing comprehensive adaptation-mitigation programs and disaster risk reduction strategies. Indonesia has set ambitious goals regarding sustainable consumption and production in terms of food, water and energy. ${ }^{33}$.

GHG emission reduction is carried out by means of mitigation and adaptation. Mitigation efforts are carried out by taking significant steps to reduce emissions from the land-based sector by adopting a moratorium policy on logging of primary forest and prohibiting conversion of the remaining forest with activities to reduce deforestation and forest degradation, restoration of ecosystem functions, and sustainable forest management including social forestry through the active participation of the private sector, small and medium enterprises, civil society organizations, local communities and the most vulnerable groups of society, especially indigenous peoples, and women - both in 
the planning and implementation stages. Landscape scale approach and ecosystem based management with role of local government,

In the energy sector, Indonesia has determined the energy mix policy. In addition, a national policy on the development of clean energy sources has also been established. Collectively, these policies will put Indonesia on a path to decarbonization. Government Regulation Number 79/2014 concerning National Energy Policy sets out the ambition to transform, in 2025 and 2050, the main energy supply mix is as follows:

a. New renewable energy at least $23 \%$ in 2025 and at least $31 \%$ in 2050;

b. Oil must be less than $25 \%$ in 2025 and less than $20 \%$ in 2050;

c. Coal at least $30 \%$ in 2025 and at least $25 \%$ in 2050;

d. Gas is at least $22 \%$ in 2025 and at least $24 \%$ in 2050 .

In the waste management sector, the Government of Indonesia is committed to developing a comprehensive strategy to improve the quality of policies and institutional capacities at the local level, increase the capacity of urban wastewater management, reduce waste disposed of into landfills through the "Reduce, Reuse, Recycle" approach, and use waste and waste for energy. The Indonesian government is committed to further reducing GHG emissions from the waste management sector by 2030 and beyond through comprehensive and coherent policy development, strengthening institutions, improving financial and funding mechanisms, technological innovation, and socio-cultural approaches.

Adaptation efforts are carried out by compiling and implementing the National Action Plan for Climate Change Adaptation (RAN-API) which provides a framework for various adaptation initiatives that have been mainstreamed into national development planning.

The Indonesian government will step up action to assess and map regional vulnerabilities as the basis for adaptation information systems, as well as strengthen institutional capacity and establish policies and regulations related to climate change by 2020 . The medium-term objective of the climate change adaptation strategy in Indonesia is to reduce risks to all development sector (agriculture, water resources, energy security, forestry, maritime and fisheries, health, public services, infrastructure, and urban systems) by 2030 through strengthening local capacities, improved knowledge management, convergent policies on climate change adaptation and disaster risk reduction, and the application of adaptive technology.

\section{CONCLUSION}

National economic growth to achieve a prosperous and prosperous society rests heavily on driving factors for national energy growth. On the other hand, population growth, an increase in the need for living standards, limited energy resources and an increase in population are challenges for meeting energy needs, especially electricity in Indonesia. One solution, the growth of electricity energy in Indonesia today must be based on the diversity of energy resources, including new resources, while Indonesia's 
readiness to apply nuclear energy as energy for sustainable development is carried out by ratifying international conventions, issuing laws, and issuing laws. regulations from the Nuclear Energy Regulatory Agency. In the infrastructure sector, Indonesia already has 3 (three) research reactors that are used for mastery of technology, also supported by the human resources owned by Indonesia who are able to apply science in the nuclear field. Indonesia's readiness is also written in Indonesia's National Determined Contribution where Indonesia is committed to reducing $26 \%$ of greenhouse gas emissions by 2020 , and up to $41 \%$ with international support.

\section{Books:}

\section{BIBLIOGRAPHY}

Anggito, A., \& Setiawan, J., 2018, Metodologi penelitian kualitatif, CV Jejak (Jejak Publisher);

Djarot Sulistyo Wisnu Broto, 2016, SDM Indonesia Mampu Bangun PLTN, Perpustakaan Badan Pengawas Tenaga Nuklir - BAPETEN;

Gro Harlem Brundtland, 1987, The Report Our Common Future, the World Commission on Environment and Development;

Hendriyanto Haditjahyono, 2010, Penyiapan SDM Untuk PLTN Pertama di Indonesia, STTN_BATAN dan Fakultas Saintek UIN SUKA, Seminar Nasional VI SDM Teknologi Nuklir, Yogyakarta;

International Atomic Energy Agency, 2016, Nuclear Power and Sustainable Development, Marketing and Sales Unit, Publishing Section of International Atomic Energy Agency, Vienna;

Neumayer, E., 2003, Weak Versus Strong Sustainability, Edward Elgar Publishing, Cheltenham;

SONG SUK CHAE, 1995, End Of Mission Report, Support For The The First Nuclear Power Plant, IAEA, Viena.

Tecdoc 525, 1998, Guide Book On Training To Establish And Maintain The Qualification And Competence Of Nuclear Power Plant Oprations Personnel, IAEA, Vienna;

United Nations, 1987, Development and International Co-operation: Environment, Report of The World Commission on Environment and Development, UN document A/42/427, UN, New York;

United Nations, 2002, Plan of Implementation of the World Summit on;

Wisnu Arya Wardhana, 2006, Penyiapan SDM Untuk Persiapan, Pembangunan dan Pengoperasian PLTN Di Indonesia, Hasil penelitian untuk Orasi Ilmiah Widyaiswara Utama, Pusdiklat BATAN Jakarta;

\section{Regulations:}

UN General Assembly Resolution 3263(XXIX), adopted on 9 December 1974 
The most recent is UN General Assembly Resolution 68/27, adopted without a vote on 5 December 2013.

Head of BAPETEN Regulation No. 10 of 2008

\section{Website:}

Indonesia's National Determined Contribution, quoted from http://www4.unfccc.int/ ndcregistry / PublishedDocuments / Indonesia\% 20First / First\% 20NDC\% 20Indonesia_submitted\% 20to\% 20UNFCCC\% 20Set_November\% 20\% 202016.pdf 